\title{
Volatility of stock market and capital flow
}

\author{
Shafaq Sherazi, Habib Ahmad \\ Master in Business Administration Foundation University, Rawalpindi \\ Prof. Management Science Department Foundation University, Rawalpindi
}

\begin{abstract}
The study examines the relationship between capital flow, return of stock indices and exchange rate. This paper documents a significant relationship between capital flow and market volatility but returns of stock exchange and exchange rate are found to be insignificant. The study will be helpful for the policy makers so that they will be able to take the decision by considering the impact of capital flow.

Key words: Capital flow, stock market volatility, exchange rate, returns, Colombo stock exchange, Karachi stock exchange.
\end{abstract}

\section{Introduction:}

Because of the modern technology capital mobility increase with an accelerating role. Risk assessment analysis for the stock market after liberalization has assumed more importance in the world. Usefulness of efficient stock markets in dynamic resource is well known. Karachi Stock Exchange once again started moving in upward direction and performance of the economy of Pakistan has increased. Investigating the behavior of volatility using a new set of variables is important.

Stock market volatility is of vital important for investors. Stock return usually follows the random path and touches the maximum and minimum level. The volatility of stock price can be observed from its fluctuation from the mean. Why we Study volatility in stock market and capital flows?

The capital flow may have different effects on exchange rate and stock market volatility.

Large capital inflows can damage the economy in many ways. Capital flow raise asset bubbles and promote too much borrowing, but they also spoil the competitiveness of the export sector, they can also cause a rapid increase in rates of exchange. Open account debit of a country will build it yet further at threat to a quick setback of funds. On the other side, if central banks interfere to seize down their currencies, the increase of funds can go in front to extremely loose financial circumstances and getting higher inflation.

Our study will be important in the following ways.

Stock market volatility prediction is imperative to financial and economic agent because it signify a measure of risk exposure in their investment. The capital flow plays an important role in this regard. Unstable stock market is an important concern for policy makers because instability of the stock market creates uncertainty and affects the growth success.

The purpose of the paper is to investigate with the aim of either the capital flow from the other countries carries volatility with them or not. This study will be helpful to investigate that volatility shocks from the other countries will affect Karachi stock exchange and Colombo stock exchange.

The second important purpose is to study with the aim of either the shocks in the capital flow will affect the volatility in the exchange rate or not. In latest years volatility in equity market have turn out to be a topic of joint worry for individual stake holders. Stock return volatility cause delay in economic performance during customer spending. Stock Return instability might too have an effect on trade asset expenses. Additional, the intense instability might upset the silky performance of the monetary system and show the way to structural or method differences.

The stock market in Pakistan has had its fair contribute to trouble due to extreme speculation resulting in excessive volatility. Certainly, in the early 1990's the confidence of investors to some extent has been eroded by excessive volatility of the Pakistan Stock Markets. Wide concern of all stake holders has realized the significance of being capable to measure and forecast stock market volatility.

\section{Literature Review}

In the last decade or more there is an increase in capital mobility of funds between different countries (French \& Vishwakarma, Volatility and foreign equity flows: evidence from the Philippines, 3013). Most of the researchers attribute this increase in capital flows due to the liberalization of restrictions between countries (Erten \& Ocampo, 2013) Other researchers argue that this increase in capital flow is due to some other factors like ease in flow of money because of global banking, global liquidity (Ahmed \& Zlate, 2013). (calvo, leiderman, \& reinhart, 1993) argued that flow of the capital in any country go together with accelerated 
economic growth. It is further suggested that the flow of capital will also influence the real estate as well as stock market

(santis, 1997) give the opinion that volatility in the financial market and the existent economy enhance by the foreign capital and this volatility is not obligatory. All the days around Asian financial crisis, foreign business was a most significance source of market volatility (Wang, 2004) but since the early 1990s, in the developing countries there is significant growth in the capital flow. The practical movement has been considered to variation in the world monetary situation, variation in the monetary fundamentals, development of wealth markets and investor's behavior (Vita \& Kyaw, Determinants of capital flow to developing countries: a structural VAR analysis, 2008)

During World War 1 the international market largely disappeared with the break out. During worldwide discrepancy, monetary resistance called to account all capital flows at development markets, Asia and United States (Martin \& Taddei, 2013). In the recent year more than a few developing countries have boosted restriction on the portfolio investment by the foreign investors in their capital market (Uppal, 1998). (Boubakri, Cosset, Debab, \& Valery, 2013) study shows that cross-border portfolio investment is susceptible to different institutional indicator such as local market regulations, disclosure of information in the host country's accounting standards.

(Lipsey, Feenstra, Hahn, \& Hatsopoulos, 1999) examined that In the world economy international capital flow perform different types of function. For example, in a country the international capital flow allow the level of domestic investment to increase the country's level of saving. (Broner, Didier, Erce, \& Schmukler, 2013) demonstrate that during crisis capital flows are unpredictable, cyclical and refused. (Insaidoo \& Biekpe, 2011) an essential key feature of ensuing discussing is how the increased capital flow affects investment volatility.

For countries that are producing the large amount of economy, global capital flows give suggestion to put in where profits are privileged than at home, as it happened in Great Britain and Japan in the nineteenth century (Lipsey, Feenstra, Hahn, \& Hatsopoulos, 1999). Capital flow might provide a number functions in shorter period such as level of various form of cyclical or financial instability (Lipsey, Feenstra, Hahn, \& Hatsopoulos, 1999)

(Wang, 2004) recommend that large capital inflows are probably to be destabilize direct to regional contagion and financial crisis. One of the most striking in the world economy over the last thirty years represents large increase in global capital flows and In recent years global capital flows increase. (Insaidoo \& Biekpe, 2011) and (Razin \& Rose, 1994) conflict that the impact of greater than before capital mobility on investment volatility is also determined by the nature of the primary productivity shocks. Increase capital Mobility will enhance the volatility of investment if country-specific shocks are persistent. He pointed out that deep financial market Lead to lower economic volatility. He also Confirm the hypothesis that domestic financial depth raise the Investment rate. (Razin \& Rose, 1994) also believes that the impact of international Volatility of investment capital mobility depends on the persistence of productivity shocks. Including this study, (Razin \& Rose, 1994) have examined the impact of volatility of international capital flows of the investment. However, these studies do not provide any understandable facts on the link between capital flow and investment volatility.

Facts on International capital flows recommend that foreign direct investment (FDI) is not as much of volatile than other financial flows. (Albuquerque, 2002). (Neumann, Penl, \& Tanku, 2006) assumed that frequently foreign direct investment is more well-known than other types of flows. Foreign direct investment arguably might be less sensitive due to its long-term sudden reversals nature of property. (Razin \& Rose, 1994) found that increase investment volatility due to the increased cross-border capital flows improves substitution possibilities between domestic and foreign investments.

Recently researchers (Alfaro, Ozcan, \& Volosovych, 2007) worked on minimization of unpredictability in global capital markets. Exclusive of a complete accepting of the determinants of capital flows and their unpredictability, it is complicated to select proposal that have been moderate negative effects on international capital mobility. One of the most important issues is global capital flows plus their cost used for monetary increase determinants.

With an increase in international capital flows, Series of economic crises in the past three decades has provided high Concerns about the impact on the national economy flow. (Insaidoo \& Biekpe, 2011). (KOSE, PRASAD, \& TERRONES, 2003) find that Output volatility increases when Volatility of consumption decreases with increasing financial integration. The major difference between the changes in the volatility of Production and consumption is generally due to the capital and risk sharing implication of different asset market structures. Capital flows in developing countries are capable to carry rapid changes in the way of Boom-bust cycle, most of which do not have profound financial sector to deal with extremely volatile capital flow. (KOSE, PRASAD, \& TERRONES, 2003) also find that country range is an significant issue and developing wealth are comparatively lesser than the developed countries.

(Andreou, Matsi, \& Savvides, 2013) In 1990's liberalization of stock market and capital flow there was immense increase in securities and currency. (Bacchetta \& Wincoop, 2000) seen significant financial 
liberalization where the countries have experienced overshooting of capital flow. Argentina is an example that liberalized capital flows at early stage since 1989, foreigners with the prior approval may invest in Argentina like Argentinean investors and since 1990 capital flows to Argentina considerably higher than a long run steady state level (Bacchetta \& Wincoop, 2000)

Capital flows liberalization have important effect on FDI flows for emerging markets and imperative negative effect on other capital flows (banking and other general types of flow including debt). (Neumann, Penl, \& Tanku, 2006)

The favors to the foreign investors look quite obvious and stem for the most part from higher predictable long term rates of return and chances of risk diversification. Return on investment in rising markets to a global index showed a low correlation with each other and they often exhibit the low correlations (Bosworth, Collins, \& Reinhart, 1999). There is greater and rapid effect on capital flow, when the time limit given to the investors is short. (Vita \& Kyaw, Determinants of capital flows to developing countries:a structural VAR analysis, 2008) Stock market volatility increase to some extent with increasing long-term exchange rate volatility, probably because the exchange rate affects profitability. Their results also show that there are no strong opinions in favor of international capital restrictions to decrease volatility. (stokman \& Vlaar, 1996). (KOSE, PRASAD, \& TERRONES, 2003) documented a negative relationship between volatility and growth means that volatility has first-order effects on welfare, even for developing economics where growth has traditionally been the major.

(Rizwan \& Khan, June 2007) high levels of volatility in financial monetary mediator create choice stand on top of the ideas with the aim of cause general attrition of investor assurance and flow of capital away from stock markets, so for making this decision the financial data of accurate measurement is considerable. (Lensink \& Morrissey, 2011) studied that Countries with export policy promotion have a stronger effect on growth than the countries that pursue the import policy substitution.

Theoretical literature of (Insaidoo \& Biekpe, 2011) forecast that international financial integration should enhance the volatility of investment. As soon as Restrictions on cross-border capital flows are reduced, chance of possibilities of substituting foreign for domestic investments increase, resulting increase in the volatility of investment leads. In case of greater volatility, some developing market economics observed "sudden stop" in international capital inflows in the 1960s and early 2000s, with serious adverse effects on macroeconomic performance (Masahiro \& Shinji, 2008)

\section{Methodology}

Different methods are employed to measure the flow of funds from one country to the other for example (French \& Vishwakarma, Volatility and foreign equity flows: evidence from the Philippines, 3013) demonstrate that equity flow to measure the affect of equity flows on Pilipino stock exchange. Other taken bond flow to measure the flow of funds from one region to the other (Jotikasthira, Lundblad, \& Ramadorai, 2012). Most of the researchers took FDI as a proxy for capital flow (Abbott, Cushman, \& Vita, 2012). (Yusuf, 2013) and (Hermes \& Lensink, 2003) recognize that FDI is considered as a catalyst to accelerate economic growth.

Table 1: Correlation Matrix

\begin{tabular}{lllll}
\hline & Return & Exchange Rate & Capital Flow & Volatility \\
\hline Returns & 1.000 & & & \\
Exchange Rate & -0.0253 & 1.000 & & \\
Volatility & 0.1803 & 0.0282 & 1.000 & 1.000 \\
$\begin{array}{l}\text { Co } \\
\text { efficient }\end{array}$ & -0.0916 & 0.0086 & 0.4964 & \\
\hline
\end{tabular}

First the data is converted in to panel and regression is applied. The outcomes of the regression are detailed in Table 2. From the results we found that stock market return are unaffected by capital flow, but volatility of the returns increases when there is capital flow in the country. The affect of capital flow on exchange rate is also found to be insignificant. No heteroskedasticity and multicollinarity is found in the data. The difference between capital inflow and outflow is taken as proxy for capital flow. 
Table 2: $t$-stats, coefficients and $p$ value of regression analysis

\begin{tabular}{llll} 
& Coefficient & T-Short & P-Value \\
\hline Returns & 0.0564 & 1.40 & 0.168 \\
Volatility & 0.131 & 4.36 & 0.000 \\
Exchange Rate & 0.021 & 0.21 & 0.831 \\
\hline
\end{tabular}

\section{Result:}

Two countries Pakistan and Sri Lanka are selected to check the affect of capital flow on stock market returns, volatility in stock returns and exchange rate. Main stock exchanges of Pakistan (Karachi stock exchange) and Sri Lanka (Colombo stock exchange) are selected for the analysis. Returns of KSE-100 Index and CSE-100 Index are calculated by using formula $\left(\mathrm{P}_{\mathrm{n}} / \mathrm{P}_{\mathrm{n}-1}\right)-1$. Volatility of return is calculated by using Garch variance series. Exchange rate of Pakistan and Sri Lanka with respect to US dollar is used in the analysis.

\section{Conclusion:}

The paper conclude that the affect of capital flow in Sri Lanka and Pakistan is increasing the volatility of stock market of these countries so it mean that the capital flow from other countries will brought in additional volatility in these markets. The returns of these stock exchanges are not affected by the capital transmission from the other countries.

\section{References:}

[1]. Abbott, A., Cushman, D. O., \& Vita, G. D. (2012). Exchange Rate Regimes and Foreign Direct Investment Flows to Developing Countries. Review of International Economics , 20 (1), 95-107.

[2]. Ahmad, H., \& Naeem, K. (2013). Impact of futures on spot price volatility. International Research Journal of Finance and Economics , 20 (1), 20-31.

[3]. Ahmed, S., \& Zlate, A. (2013). Capital Flows to Emerging Market Economies: A Brave New World? 1-57.

[4]. Albuquerque, R. (2002). The Composition of International Capital Flow: Risk Sharing Through Foreign Direct Investment. 1-42.

[5]. Alfaro, L., Ozcan, S. K., \& Volosovych, V. (2007). Capital Flows in a Globalized World: The Role of Policies and Institutions. 1971.

[6]. Andreou, E., Matsi, M., \& Savvides, A. (2013). Stock and Foreign Exchange Market Linkages in Emerging Economies. Department of Economics , 1-40.

[7]. Bacchetta, P., \& Wincoop, E. v. (2000). Capital Flows to Emerging Markets Liberalization, Overshooting, and Volatility. 61-104.

[8]. Bosworth, B. p., Collins, S. M., \& Reinhart, C. M. (1999). Capital flow to developing economies: Implications of saving and investment. The brooking institution, 1999 (1), 143-180.

[9]. Boubakri, N., Cosset, J. C., Debab, N., \& Valery, P. (2013). Privatization and globalization: An empirical analysis. Journal of Banking \& Finance, 1898-1914.

[10]. Broner, F., Didier, T., Erce, A., \& Schmukler, S. L. (2013). Gross capital flows: Dynamics and crises. Journal of Monetary Economics, 113-133.

[11]. calvo, g. A., leiderman, 1., \& reinhart, c. M. (1993). capital inflow and real exchange rate appriciation in latian america. international monetary funds , 40 (1), 108-151.

[12]. Contessi, S., Pace, P. D., \& Francis, J. L. (2013). The cyclical properties of disaggregated capitalflows. Journal of International Money and Finance, 528-555.

[13]. Determinants of capital flows to developing countries: a structural VAR analysis. (2008). Journal of Economic Studies , 35 (4), $304-$ 322.

[14]. Erten, B., \& Ocampo, J. A. (2013). Capital Account Regulations, Foreign Exchange Pressure, and Crisis Resilience. 1-32.

[15]. French, J. J., \& Ahmad, N. (2011). Returns or valuation? Foreign equity investment. Studies in Economics and Finance , 28 (3), 196-216.

[16]. French, J. J., \& Vishwakarma, V. K. (2013). Volatility and foreign equity flows: evidence from the Philippines. Studies in Economics and Finance, 30 (1), 4-21.

[17]. French, J. J., \& Vishwakarma, V. K. (3013). Volatility and foreign equity flows: evidence from the Philippines. Studies in Economics and Finance, 30 (1), 4-21.

[18]. Hermes, N., \& Lensink, R. (2003). FOREIGN DIRECT INVESTMENT, FINANCIAL DEVELOPMENT AND ECONOMIC GROWTH. The Journal of Development Studies , 38, 1-42.

[19]. Insaidoo, W. B., \& Biekpe, N. (2011). International capital flows and investment volatility in selected sub-Saharan African countries. Review of Development Finance, 223-228.

[20]. Jotikasthira, C., Lundblad, C., \& Ramadorai, T. (2012). Asset Fire Sales and Purchases and the International Transmission of Financial Shocks. The Journal of Finance, 67 (6), 2015-2050.

[21]. KOSE, M. A., PRASAD, E. S., \& TERRONES, M. E. (2003). Financial Integration and Macroeconomic Volatility. 50, 119-142.

[22]. Lensink, R., \& Morrissey, O. (2011). FOREIGN DIRECT INVESTMENT: FLOWS, VOLATILITY AND GROWTH. 1-32.

[23]. Lipsey, R. E., Feenstra, R. C., Hahn, C. H., \& Hatsopoulos, G. N. (1999). The Role of Foreign Direct Investment in International Capital Flows. 307 - 362.

[24]. Martin, A., \& Taddei, F. (2013). International capital flows and credit market imperfections: A tale of two frictions. Journal of International Economics , 441-452.

[25]. Masahiro, K., \& Shinji, T. (2008). A survey of the literature on managing capital inflows.

[26]. Neumann, R. M., Penl, R., \& Tanku, A. (2006). Volatility of Capital Flows and Financial Liberalization: Do Specific Flows Respond Differently? 1-53.

[27]. Razin, A., \& Rose, A. K. (1994). Business Cycle Volatility and Openness: An Exploratory Cross-Section Analysis. National Bureau of Economic Research , 1-31. 
[28]. Rizwan, M. F., \& Khan, S. U. (June 2007). Stock Return Volatility in Emerging Equity Market (Kse): The Relative Effects of Country and Global Factors. International Review of Business Research Papers , 3 (2), 362-375.

[29]. santis, G. D. (1997). Stock returns and volatility in emerging financial markets. Journal of International Money and Finance, 16 (4), 561-579.

[30]. stokman, A. J., \& Vlaar, P. J. (1996). Volatility, International Trade and Capital Flows. 32, 115-132.

[31]. Uppal, J. Y. (1998). Stock return volatility in an emerging market: A case study of karachi stock exchange. Department of business and economics, 24 (3), 34-51

[32]. Wang, J. (2004). Foreign Equity Trading and Emerging Market Volatility: Evidence from Indonesia and Thailand. School of Banking \& Finance, 1-38.

[33]. Yang, H., Xiong, Y., \& Ze, Y. (2013). A Comparative Study of Determinants of International Capital Flows to Asian and Latin American Emerging Countries. Procedia Computer Science, 1258 - 1265.

[34]. Yusuf, S. (2013). Can Chinese FDI Accelerate Can Chinese FDI Accelerate. 1-45. 